\title{
Antibody-Dependent Cellular Cytotoxicity and NK Cell-Driven Immune Escape in HIV Infection: Implications for HIV Vaccine Development
}

\author{
Gamze Isitman, Ivan Stratov, and Stephen J. Kent \\ Department of Microbiology and Immunology, University of Melbourne, Melbourne, VIC 3010, Australia \\ Correspondence should be addressed to Stephen J. Kent, skent@unimelb.edu.au
}

Received 11 January 2012; Revised 13 February 2012; Accepted 13 February 2012

Academic Editor: Christoph Boesecke

Copyright (c) 2012 Gamze Isitman et al. This is an open access article distributed under the Creative Commons Attribution License, which permits unrestricted use, distribution, and reproduction in any medium, provided the original work is properly cited.

\begin{abstract}
The HIV-1 genome is malleable and a difficult target tot vaccinate against. It has long been recognised that cytotoxic T lymphocytes and neutralising antibodies readily select for immune escape HIV variants. It is now also clear that NK cells can also select for immune escape. NK cells force immune escape through both direct Killer-immunoglobulin-like receptor (KIR)-mediated killing as well as through facilitating antibody-dependent cellular cytotoxicity (ADCC). These newer finding suggest NK cells and ADCC responses apply significant pressure to the virus. There is an opportunity to harness these immune responses in the design of more effective HIV vaccines.
\end{abstract}

\section{Introduction}

The human immunodeficiency virus (HIV-1) pandemic is causing substantial morbidity and mortality across the globe, particularly in developing countries. Antiretroviral drug therapy for HIV is highly effective in controlling disease; however, eradication of HIV-1 is currently not feasible so treatment is life long and is both expensive and leads to considerable toxicity and drug resistance. A vaccine is widely viewed as being essential to controlling the epidemic. Several advanced efforts to develop an effective vaccine have failed or shown only marginal efficacy to date [1-4]. One of the greatest challenges in developing a vaccine against HIV is to overcome its ability to constantly mutate and escape antiHIV immune responses. This high mutation rate is a direct result of the presence of the virus' low fidelity RNA polymerase enzyme as well as the high levels of recombination it undergoes $[5,6]$.

A measure of the pressure immune responses apply is through their ability to force viral mutations that result in escape from immune recognition. Both CTLs and Nabs have long been reported to select for immune escape variants during the course of HIV-1 infection [7, 8]. Much effort in vaccine development centers on inducing broad and potent
CTL (cytotoxic T lymphocyte) and Nab (Neutralizing antibody) responses to conserved viral epitopes and restricting opportunities for viral escape. However, it is now also recognised other immune responses, such as antibody-dependent cellular cytotoxicity (ADCC) and NK cells, select for immune escape variants, suggesting additional immune responses apply significant pressure to the virus [9]. ADCC responses mediated by effector NK cells may be useful responses to induce by vaccination. This paper summarizes current thinking on immune escape from anti-HIV immune responses.

\section{CTL Escape and the Road to Reduced Viral Fitness}

Immune escape from HIV was first demonstrated for CTLbased immunity in 1991 [8]. Considerable work since then has shown CTL escape is typically regulated by the effect of the escape mutation on comparative viral fitness, a complex parameter illustrating the overall contribution of all mutation-related advantages and losses (Table 1). Even though the evasion of immune responses presented by escape mutations presents a definite fitness benefit to the virus, the HIV-1 proteome is not infinitely malleable hence the same 
TABLE 1: Key escape papers.

\begin{tabular}{|c|c|c|c|}
\hline $\begin{array}{l}\text { Immune } \\
\text { response }\end{array}$ & Hypothesis & Result & Ref. \\
\hline \multirow{3}{*}{ CTL based } & $\begin{array}{l}\text { HLA-B*57/B*5801 CTL escape } \\
\text { mutations in Gag impacts viral } \\
\text { replication in vivo }\end{array}$ & $\begin{array}{l}\text { Reductions in relative replication } \\
\text { capacity reduce "viral fitness" }\end{array}$ & {$[20]$} \\
\hline & $\begin{array}{l}\text { CTL escape mutations in Env do not } \\
\text { result in reduced viral fitness }\end{array}$ & $\begin{array}{l}\text { Escape mutations within Env-specific } \\
\text { CTL are epitopes evident but no } \\
\text { correlation with reduced SIV replication }\end{array}$ & [25] \\
\hline & $\begin{array}{l}\text { Step HIV-1 vaccine trial exerts selective } \\
\text { CTL pressure on HIV-1 }\end{array}$ & $\begin{array}{l}\text { Extended sequence divergence for vaccine } \\
\text { recipients who become infected suggests } \\
\text { vaccine-induced CTL imparted } \\
\text { significant immune pressure } \\
\text { Gag- } 84 \text { most significant signature site }\end{array}$ & {$[36]$} \\
\hline \multirow{3}{*}{ Nab based } & $\begin{array}{l}\text { Evolving "glycan shield" mechanism } \\
\text { prevents Nab binding }\end{array}$ & $\begin{array}{l}\text { Env gene mutations in escape virus sparse } \\
\text { Escape mutations did not map to known } \\
\text { epitopes } \\
\text { Efficient neutralization requires potent, } \\
\text { high titres }\end{array}$ & {$[54]$} \\
\hline & $\begin{array}{l}\text { Continual selection of } \mathrm{Nab} \text { escape } \\
\text { variants occurs }\end{array}$ & $\begin{array}{l}\text { All previous viral isolates, but not } \\
\text { concurrent isolate, are recognised by } \\
\text { concurrent Nab }\end{array}$ & {$[7]$} \\
\hline & $\begin{array}{l}\text { Passive transfer of human neutralizing } \\
\text { monoclional antibodies delays HIV-1 } \\
\text { rebound post-antiretroviral therapy }\end{array}$ & $\begin{array}{l}2 \mathrm{G} 12 \text { monoclonal was crucial for } \\
\text { transient in vivo effect of Nab cocktail but } \\
\text { immune escape resulted }\end{array}$ & {$[55]$} \\
\hline \multirow[t]{2}{*}{ ADCC based } & $\begin{array}{l}\text { Immune pressure from HIV-specific } \\
\text { ADCC results in immune-escape variants }\end{array}$ & $\begin{array}{l}\text { ADCC causes escape in multiple epitopes } \\
\text { and evolves over timeADCC antibodies } \\
\text { forcing immune escape can be } \\
\text { non-eutralizing }\end{array}$ & [9] \\
\hline & $\begin{array}{l}\text { NK cells apply immunological pressure } \\
\text { on HIV-1 through direct killing of } \\
\text { infected cells }\end{array}$ & $\begin{array}{l}\text { HIV-1 selects KIR2DL2+ virus mutations } \\
\text { that result in reduced antiviral activity of } \\
\text { NK cells }\end{array}$ & [85] \\
\hline
\end{tabular}

mutations can result in fitness costs. Some CTL immune escape variants have reduced replicative capacity of the virus (reduced "fitness") that slows the progression of disease $[10,11]$. Studies have demonstrated that certain viruses composed of immune escape mutations are associated with lower viral loads within subjects $[12,13]$. It has also been suggested that the rate of viral escape likely reflects the strength of the immune pressure and the fitness cost of the mutant virus [14]. Fitness costs are most dramatically illustrated in vivo by the reversion of transmitted escape mutations during acute and early HIV-1 infection [15-19].

Several CTL escape mutations have been confirmed to disrupt normal virus protein structure and/or function [20-23]. More than half of deleterious escape mutations have been verified in the relatively conserved Gag protein, whereas Troyer et al. [24] recently presented that CTL escape mutations in Env did not commonly transfer an associated fitness cost and indeed in a number of cases strengthened competitive viral fitness. This result is consistent with the lack of reversion of Env CTL escape mutations in vivo [25, 26]. Macaque and human studies have also demonstrated that escape from T-cell immunity leads to ongoing HIV or SIV infection [27]. The latest investigation of the effect on viral replication of twenty CTL escape mutations in Gag epitopes established only three escape mutations that resulted in substantial reductions in viral replication capacity, indicating that high-cost escape mutations are rather rare [28]. More importantly, these three highly effective CTL escape mutations appeared in epitopes primarily targeted during acute infection by protective HLA class I alleles [29]. This demonstrates that the protection allowed by certain HLA class I alleles may arise because the barrier to viral escape in the targeted epitope is high leading to either maintenance of a dominant and effective CD8+ T-cell response, and/or attenuation of virus replication from selection of high-cost escape mutations. Examination of viruses derived from HIV-1 controllers (individuals who maintain long-term control of HIV-1 viremia) reveal evidence of a role for rare or novel CTL escapeassociated fitness costs in control of HIV-1 replication [3033].

CTL responses and the immune escape variants induced are also important in HIV transmission scenarios. Two recent reports detail early clinical correlates related with the transmission of viruses expressing a number of CTL escape mutations known to weaken in vitro replication capacity $[12,34]$. As the transmitted escape mutations revert to wild type [23], these enhanced results associated with such transmissions have been perceived to decline and the long-term clinical outcome of these transient effects remains unforeseeable. With improved characterization of the virology of acute 
HIV-1 infection differences in founder virus, replication compared with viral escape strains caused by dominant CD8+ T-cell responses is becoming easier to model. The distinctions between the founder virus and viral escape strains may contribute to observed variability in the immune control of HIV-1 replication, which may be caused by carry-over mutations and variation in the rate of escape related to fitness costs from key CD8+ T-cell responses, in return influencing set-point viral load and early clinical disease course [35]. Elite control of viral replication may in part be due to the transmission of a virus attenuated by accumulated carryover mutations from hosts with such principal CD8+ T-cell responses to escape associated epitopes resulting in high fitness costs. Rolland et al. recently illustrated the first evidence of selective pressure from vaccine-induced T-cell responses on HIV-1 infection by analyzing HIV-1 genome sequences from 68 volunteers who participated in the STEP Adenovirus-vector HIV-1 vaccine efficacy trial [36]. Comparison of T-cell epitopes in the founder sequences to epitopes in the vaccine distinguished greater breadth for sequences from vaccine recipients than from placebo recipients, suggesting the vaccine imparted important immune pressure to the selection of the infecting isolates. Vaccine-induced fitness-impaired virus could, if sufficiently potent, translate into a reduction in viral loads and attenuation of disease progression.

\section{The Great Escape from Neutralizing Antibodies}

Considerable data exist illustrating the effect of neutralizing antibodies in protecting against HIV-1 infection in vitro [37, 38 ] and in vivo using animal models [39-46]. Although antibodies are made to all HIV proteins within a few weeks, only those to the envelope glycoproteins can prevent or neutralize HIV infection. These neutralizing antibodies ( $\mathrm{Nab}$ ) take considerably longer to develop than binding antibodies, generally months to years [47]. HIV-infected subjects almost always develop Nab to their own virus (autologous neutralization), although Nabs typically respond to earlier viral isolates, with the subject's contemporaneous virus having escaped. Some subjects eventually develop Nabs able to cross-neutralize additional viruses (heterologous neutralization), but their concurrent virus is still usually escaped from their autologous Nab. This highlights many of the difficulties involved in controlling HIV replication by Nab and the ability of HIV to escape antibody pressure through a process of genetic change [38]. The envelope gene presents the highest ratio of genetic diversity, most likely as a direct result of $\mathrm{Nab}$ pressure. However, for the virus to remain infective, portions of the envelope gene that encode regions essential for functional activity, such as CD4 and coreceptor binding, need to be conserved, and hence escape from Env Nabs probably results in little fitness cost. Individuals who do develop outstanding $\mathrm{Nab}$ responses generally have antibodies directed towards such crucial functional regions [48]. Long-term nonprogressors who have remained symptom-free for many years without antiretroviral therapy in general have broader and more potent responses compared to persons who show progressive disease [49-53].

Escape from neutralizing antibody responses often involves serial changes in glycosylation patterns and small insertions and deletions [7]. Richman and colleagues found that 9 of 12 untreated patients with detectable neutralizing antibody had the highest neutralising antibody titer towards against the baseline virus (month 0 ) whereas only three subjects showed higher titers of neutralizing antibody against viruses that appeared later in infection [7]. Wei and colleagues clearly illustrated the inhibition of HIV1 by Nabs when successive populations of resistant virus were completely substituted by neutralization-sensitive virus [54]. Furthermore, they showed escape virus contained infrequent mutations in the env gene, generally mapped to unknown neutralization epitopes, and involved changes mainly in N-linked glycosylation sites. This pattern of escape led to the hypothesis of an evolving "glycan shield" mechanism of neutralization escape which selected differences in glycan packing preventing Nab binding but not receptor binding. Mutational substitution assays showed that Nabselected alterations in glycosylation presented escape from both autologous antibody and epitope-specific monoclonal antibodies. Thus a new mechanism was presented contributing to HIV-1 persistence in the presence of an antibody repertoire.

Viral escape regardless of the presence of neutralizing antibodies could demonstrate either that antibodies were ineffective in vivo, in which case antibody-sensitive viral strains would remain, or otherwise that the virus escaped the pressure applied by the antibody. Trkola et al. illustrated that passive transfer of Nabs in humans with established HIV resulted in immune escape by comparing the inhibitory activity of 3 monoclonal Nabs (2F5, 4E10 and 2G12) against virus isolates derived before the passive transfer trial and to sequential isolates after antibody treatment [55]. There was a strong association between development of 2G12-resistant viral strains and emergence of escape mutants to this antibody, failure to respond to treatment and loss of viremia control. While evidence of virus escape implies Nab selective pressure to a certain extent $[7,54,55]$, it has been speculated that postinfection Nabs could exert only a limited suppressive effect on primary HIV replication [45, 56, 57]. Prevention of primary SIV or SHIV replication in monkeys by passive $\mathrm{Nab}$ immunization prior to or very early after infection is achievable $[40,58-60]$. Taken together, this suggests that HIV control by potent Nabs is most likely to be effective prior to infection. Immune escape is likely to compromise the role of Nabs after infection is already manifested.

The role of neutralizing antibodies in preventing or limiting HIV-1 infection is becoming clearer with a better understanding of the structure of the envelope glycoprotein as well as passive immunization studies in animals showing that antibodies can indeed control infection. Further insights into neutralization-sensitive epitopes on the envelope glycoprotein are needed that will enable us to design better vaccine immunogens in vaccines. Ultimately this should allow the ability to induce neutralizing antibodies in conjunction with additional antibody-mediated protective mechanisms such 


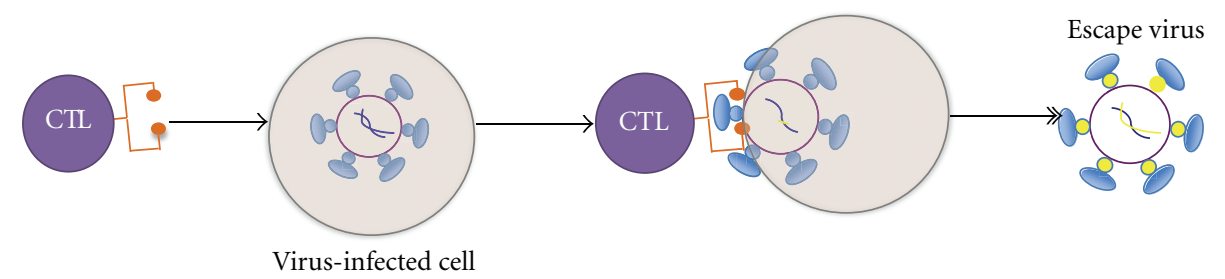

(a)

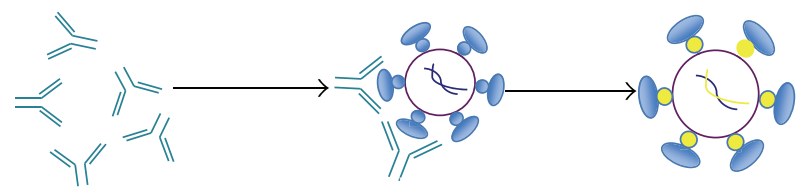

(b)

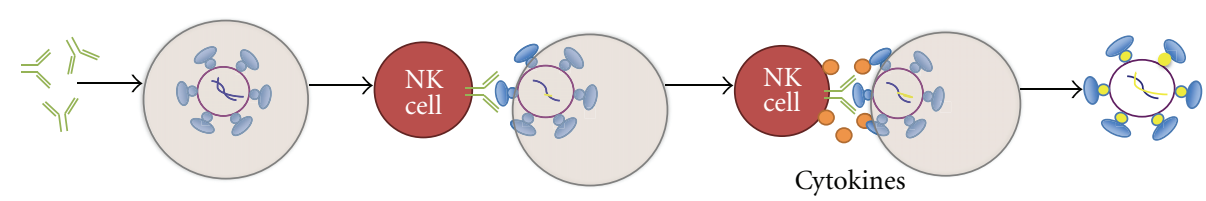

(c)

Figure 1: HIV-specific immune responses force immune escape. The mechanism of immune pressure applied by Cytotoxic T lymphocytes (a), neutralizing antibodies (b), and ADCC antibodies (1) is illustrated. Escape from immune responses shows results once free virus (Nab responses) or viral particles are presented either via the MHC class pathway (CTL responses) or possibly on the surface of the infected cell by virus budding (ADCC).

as antibody-dependent cell-mediated cytotoxicity (ADCC) in the fight against HIV.

\section{Escape from ADCC}

Sequencing single HIV genomes from subjects with acute HIV-1 infection reveals that multiple mutations are acquired during the first months of infection and most align with sites of CTL or Nab escape mutations [61, 62]. However, some mutations do not clearly map to known sites of CTL or Nab escape, suggesting there may be other immune responses, such as ADCC responses, sufficiently potent to select immune escape strains. ADCC antibodies bind to viral antigens on the surface of infected cells and engage Fc receptors on innate immune cells such as NK cells, macrophages, and neutrophils, which in turn lyse the HIV-infected cell (Figure 1(c)).

ADCC is an area relatively poorly explored in HIV immunology in recent years. Very few ADCC epitopes have been identified to date within HIV. The majority of these identified ADCC epitopes are within Env glycoproteins, gp120 [63-66] and gp41 [67-69], Tat [70] and Nef [71, 72].

Several recent studies in both humans and macaques are now suggesting that ADCC antibodies can be effective in controlling HIV or SIV $[4,73,74]$. The potent immune pressure that can be applied by HIV-specific ADCC antibodies has only recently been brought into sharper focus. Importantly, Hessell and colleagues performed experiments on Nab mutated in the Fc region, which showed a reduced ability of the Nab to mediate killing of infected cells in vitro.
When they administered the mutant (Fc defective) Nab to macaques, they were also markedly reduced in their ability to prevent SHIV infection [73]. It perhaps should be no surprise that ADCC antibodies are also implicated in viral escape as the HIV genome is able to make multiple changes to avoid CTL, Nab, and antiretroviral drug pressure.

ADCC responses forcing immune escape had until recently not previously been demonstrated. Demonstrating viral escape from ADCC responses would strongly suggest that ADCC responses exert significant pressure on the immune system [75]. Stratov et al. described a novel assay which allowed the mapping of a series of HIV-specific ADCC epitopes in subjects infected with HIV, using a set of consensus HIV peptides [76]. The identified epitopes within the subjects HIV strains were then further cloned and sequenced across the relevant epitopes and analyzed as to whether their ADCC responses were able to recognize their own virus strain. Evidence of immune escape was found against multiple HIV-specific ADCC epitopes studied in the Env protein of HIV-1 [9]. Evolution of escape over time was detected in contemporary plasma samples, which differed significantly from initial viral sequences at areas targeted by ADCC.

ADCC antibody responses are generally thought to target viral surface proteins presented on the surface of infected cells. Our group has also identified ADCC responses to viral peptides derived from internal $\mathrm{HIV}-1$ proteins such as $\mathrm{Vpu}$ and Pol [75, 76]. Interestingly, we also identified possible immune escape to an epitope of the highly conserved protein Pol [77]. It is not immediately apparent how these epitopes would be presented on the surface of cells to ADCC antibodies and force viral escape and much more work needs to be 
done to define whether ADCC antibodies to internal proteins can recognize $\mathrm{HIV}$-infected cells in vitro. We speculate that it may also be possible that ADCC recognition of viral debris on the surface of healthy neighboring cells may trigger noncytolytic activity from NK cells that could limit HIV-1 spread in a local environment. Such a mechanism would also be susceptible to immune escape.

Using ADCC peptide epitopes and an NK-cell activation assay, the hypothesis that ADCC plays a major part in the immune response against HIV was confirmed. This work likely underestimates the number of ADCC epitopes targeted by each HIV+ subject, since linear epitopes are readily mapped and dissected and consensus B overlapping peptides are used for screening. Conformational ADCC antibodies are likely to elicit escape also but to map such responses and identify escape patterns will be more difficult and require large numbers of mutant whole Env proteins.

The partial efficacy shown by the recently reported canarypox prime/protein boost vaccine trial conducted in Thailand [78] could possibly be associated with ADCC antibodies. Recent conference presentations have correlated nonneutralizing antibody responses to vaccine efficacy, although much work remains to be done to understand this fully [79]. It is conceivable, by analogy with results on CTL responses in the STEP trial [36], that vaccinated subjects in the Thai trial who still became infected may have become infected with HIV variants already "preescaped" at the ADCC responses induced by their vaccination.

ADCC-forced mutations could theoretically incur some "fitness cost" to viral replicative capacity, similar to that observed for CTL escape variants [12]. Constructing replicating viruses with ADCC-induced mutations will allow testing of this hypothesis. More potent ADCC antibodies are likely to target conserved or functional domains of viral proteins. The Env protein is highly diverse and readily escapes CTL and Nab responses with apparent minimal fitness costs $[7,24,26,80]$. It is possible that any fitness cost of ADCC escape in Env could also be small. ADCC antibodies targeting conserved non-Env proteins such as Vpu and Pol may be more potent, although it needs to be assessed whether these antibodies recognize HIV-infected cells as noted above. It is also likely that compensatory mutations may emerge which repair any fitness cost of primary mutations [81]. Further studies on the patterns of ADCC escape and the specific cellular components involved in ADCC should allow a finer understanding of how to either limit ADCC escape or force larger fitness costs.

Natural killer (NK) cells are the key effector cells mediating ADCC function. Virally infected cells are identified through a range of activating and inhibitory receptors [82] as well as both activating and inhibitory killer immunoglobulin-like receptors (KIRs) [83, 84]. Alter and colleagues recently clearly demonstrated that NK cells can directly mediate antiviral immune pressure in vivo in humans [85]. They showed that the binding of inhibitory KIRs to HIV-1infected CD4+ T cells is amplified and the antiviral activity of KIR-positive NK cells is diminished by KIR-associated HIV1 sequence polymorphisms. Similar to immune pressure applied by virus-specific $\mathrm{T}$ cells and neutralizing antibodies, it seems plausible to state that KIR-positive NK cells can place immunological pressure on HIV-1 and that the virus can evade such NK-cell-mediated immune pressure by selecting for sequence polymorphisms.

\section{Conclusions}

CTL and Nab immune responses are pivotal drivers in immune escape and viral variability. It is now clear that the role of NK cells in viral selection, both through direct killing and ADCC mechanisms, is likely to have been previously underestimated. Other effector cells of the innate immune system, including macrophages and neutrophils, may also be important in driving HIV evolution. Evidence of the pressure applied by ADCC antibodies now provides challenges to inducing the most effective ADCC antibodies by vaccination. A better understanding of the immune responses to HIV is required to fully harness the potential of a vaccine to both prevent viral entry and ongoing infection.

\section{References}

[1] E. Iaccino, M. Schiavone, G. Fiume, I. Quinto, and G. Scala, "The aftermath of the Merck's HIV vaccine trial," Retrovirology, vol. 5, article 56, 2008.

[2] J. H. Kim, S. Rerks-Ngarm, J. L. Excler, and N. L. Michael, "HIV vaccines: lessons learned and the way forward," Current Opinion in HIV and AIDS, vol. 5, no. 5, pp. 428-434, 2010.

[3] N. A. Wilson and D. I. Watkins, "Is an HIV vaccine possible?" Brazilian Journal of Infectious Diseases, vol. 13, no. 4, pp. 304310, 2009.

[4] S. Rerks-Ngarm, P. Pitisuttithum, S. Nitayaphan et al., "Vaccination with ALVAC and AIDSVAX to prevent HIV-1 infection in Thailand," New England Journal of Medicine, vol. 361, no. 23, pp. 2209-2220, 2009.

[5] E. S. Svarovskaia, S. R. Cheslock, W. H. Zhang, W. S. Hu, and V. K. Pathak, "Retroviral mutation rates and reverse transcriptase fidelity," Frontiers in Bioscience, vol. 8, pp. d117d134, 2003.

[6] A. Onafuwa-Nuga and A. Telesnitsky, "The remarkable frequency of human immunodeficiency virus type 1 genetic recombination," Microbiology and Molecular Biology Reviews, vol. 73, no. 3, pp. 451-480, 2009.

[7] D. D. Richman, T. Wrin, S. J. Little, and C. J. Petropoulos, "Rapid evolution of the neutralizing antibody response to HIV type 1 infection," Proceedings of the National Academy of Sciences of the United States of America, vol. 100, no. 7, pp. 4144-4149, 2003.

[8] R. E. Phillips, S. Rowland-Jones, D. F. Nixon et al., "Human immunodeficiency virus genetic variation that can escape cytotoxic T cell recognition," Nature, vol. 354, no. 6353, pp. 453-459, 1991.

[9] A. W. Chung, G. Isitman, M. Navis et al., "Immune escape from HIV-specific antibody-dependent cellular cytotoxicity (ADCC) pressure," Proceedings of the National Academy of Sciences of the United States of America, vol. 108, no. 18, pp. 75057510, 2011.

[10] C. S. Fernandez, I. Stratov, R. De Rose et al., "Rapid viral escape at an immunodominant simian-human immunodeficiency virus cytotoxic T-lymphocyte epitope exacts a dramatic fitness cost," Journal of Virology, vol. 79, no. 9, pp. 5721-5731, 2005. 
[11] A. J. Leslie, K. J. Pfafferott, P. Chetty et al., "HIV evolution: CTL escape mutation and reversion after transmission," Nature Medicine, vol. 10, no. 3, pp. 282-289, 2004.

[12] P. A. Goepfert, W. Lumm, P. Farmer et al., "Transmission of HIV-1 Gag immune escape mutations is associated with reduced viral load in linked recipients," Journal of Experimental Medicine, vol. 205, no. 5, pp. 1009-1017, 2008.

[13] T. M. Allen and M. Altfeld, "Crippling HIV one mutation at a time," Journal of Experimental Medicine, vol. 205, no. 5, pp. 1003-1007, 2008.

[14] S. J. Kent, C. S. Fernandez, C. J. Dale, and M. P. Davenport, "Reversion of immune escape HIV variants upon transmission: insights into effective viral immunity," Trends in Microbiology, vol. 13, no. 6, pp. 243-246, 2005.

[15] A. J. Leslie, K. J. Pfafferott, P. Chetty et al., "HIV evolution: CTL escape mutation and reversion after transmission," Nature Medicine, vol. 10, no. 3, pp. 282-289, 2004.

[16] J. Herbeck, M. Rolland, W. Deng, A. Collier, and J. Mullins, in AIDS Vaccine, A. L. Ross, Ed., vol. 6, Paris, France, 2009.

[17] N. Goonetilleke, M. K. P. Liu, J. F. Salazar-Gonzalez et al., "The first $\mathrm{T}$ cell response to transmitted/founder virus contributes to the control of acute viremia in HIV-1 infection," Journal of Experimental Medicine, vol. 206, no. 6, pp. 1253-1272, 2009.

[18] M. Kearney, F. Maldarelli, W. Shao et al., "Human immunodeficiency virus type 1 population genetics and adaptation in newly infected individuals," Journal of Virology, vol. 83, no. 6, pp. 2715-2727, 2009.

[19] B. Li, A. D. Gladden, M. Altfeld et al., "Rapid reversion of sequence polymorphisms dominates early human immunodeficiency virus type 1 evolution," Journal of Virology, vol. 81, no. 1, pp. 193-201, 2007.

[20] C. L. Boutwell, C. F. Rowley, and M. Essex, "Reduced viral replication capacity of human immunodeficiency virus type 1 subtype $\mathrm{C}$ caused by cytotoxic-T-lymphocyte escape mutations in HLA-B57 epitopes of capsid protein," Journal of Virology, vol. 83, no. 6, pp. 2460-2468, 2009.

[21] M. A. Brockman, A. Schneidewind, M. Lahaie et al., "Escape and compensation from early HLA-B57-mediated cytotoxic Tlymphocyte pressure on human immunodeficiency virus type 1 Gag alter capsid interactions with cyclophilin A," Journal of Virology, vol. 81, no. 22, pp. 12608-12618, 2007.

[22] A. Schneidewind, M. A. Brockman, J. Sidney et al., "Structural and functional constraints limit options for cytotoxic Tlymphocyte escape in the immunodominant HLA-B27-restricted epitope in human immunodeficiency virus type 1 capsid," Journal of Virology, vol. 82, no. 11, pp. 5594-5605, 2008.

[23] H. Crawford, W. Lumm, A. Leslie et al., "Evolution of HLAB 5703 hiv-1 escape mutations in HLA-B 5703-positive individuals and their transmission recipients," Journal of Experimental Medicine, vol. 206, no. 4, pp. 909-921, 2009.

[24] R. M. Troyer, J. McNevin, Y. Liu et al., "Variable fitness impact of HIV-1 escape mutations to cytotoxic T lymphocyte (CTL) response," PLoS Pathogens, vol. 5, no. 4, 2009.

[25] V. Peut and S. J. Kent, "Substantial envelope-specific CD8 Tcell immunity fails to control siv disease," Virology, vol. 384, no. 1, pp. 21-27, 2009.

[26] V. Peut and S. J. Kent, "Utility of human immunodeficiency virus type 1 envelope as a T-cell immunogen," Journal of Virology, vol. 81, no. 23, pp. 13125-13134, 2007.

[27] D. H. Barouch, J. Kunstman, M. J. Kuroda et al., "Eventual AIDS vaccine failure in a rhesus monkey by viral escape from cytotoxic T lynphocytes," Nature, vol. 415, no. 6869, pp. 335339, 2002.
[28] C. L. Boutwell, A. Schneidewind, Z. Brumme et al., "P09-19 LB. CTL escape mutations in gag epitopes restricted by protective HLA class I alleles cause substantial reductions in viral replication capacity," Retrovirology, vol. 6, no. 3, article 1742, p. P399, 2009.

[29] H. Streeck, J. S. Jolin, Y. Qi et al., "Human immunodeficiency virus type 1 -specific $\mathrm{CD}^{+} \mathrm{T}$-cell responses during primary infection are major determinants of the viral set point and loss of CD4 $4^{+}$T cells," Journal of Virology, vol. 83, no. 15, pp. 76417648, 2009.

[30] T. Miura, M. A. Brockman, C. J. Brumme et al., "Genetic characterization of human immunodeficiency virus type 1 in elite controllers: lack of gross genetic defects or common amino acid changes," Journal of Virology, vol. 82, no. 17, pp. 84228430, 2008.

[31] T. Miura, C. J. Brumme, M. A. Brockman et al., "HLA-associated viral mutations are common in human immunodeficiency virus type 1 elite controllers," Journal of Virology, vol. 83, no. 7, pp. 3407-3412, 2009.

[32] T. Miura, M. A. Brockman, A. Schneidewind et al., "HLA-B57/ B*5801 human immunodeficiency virus type 1 elite controllers select for rare gag variants associated with reduced viral replication capacity and strong cytotoxic T-lymphotye recognition," Journal of Virology, vol. 83, no. 6, pp. 2743-2755, 2009.

[33] T. Miura, M. A. Brockman, Z. L. Brumme et al., "HLA-associated alterations in replication capacity of chimeric NL4-3 viruses carrying gag-protease from elite controllers of human immunodeficiency virus type 1," Journal of Virology, vol. 83, no. 1, pp. 140-149, 2009.

[34] D. R. Chopera, Z. Woodman, K. Mlisana et al., "Transmission of HIV-1 CTL escape variants provides HLA-mismatched recipients with a survival advantage," PLoS Pathogens, vol. 4, no. 3, Article ID e1000033, 2008.

[35] C. L. Boutwell, M. M. Rolland, J. T. Herbeck, J. I. Mullins, and T. M. Allen, "Viral evolution and escape during acute HIV-1 infection," The Journal of Infectious Diseases, vol. 202, supplement, pp. S309-S314, 2010.

[36] M. Rolland, S. Tovanabutra, A. C. Decamp et al., "Genetic impact of vaccination on breakthrough HIV-1 sequences from the STEP trial," Nature Medicine, vol. 17, no. 3, pp. 366-372, 2011.

[37] N. L. Haigwood and L. Stamatatos, "Role of neutralizing antibodies in HIV infection," AIDS, vol. 17, supplement, pp. S67-S71, 2003.

[38] P. W. Parren, J. P. Moore, D. R. Burton, and Q. J. Sattentau, "The neutralizing antibody response to HIV-1: viral evasion and escape from humoral immunity," AIDS, vol. 13, supplement, pp. S137-162, 1999.

[39] T. W. Baba, V. Liska, R. Hofmann-Lehmann et al., "Human neutralizing monoclonal antibodies of the IgG1 subtype protect against mucosal simian-human immunodeficiency virus infection," Nature Medicine, vol. 6, no. 2, pp. 200-206, 2000.

[40] J. R. Mascola, G. Stiegler, T. C. Vancott et al., "Protection of macaques against vaginal transmission of a pathogenic HIV- 1/SIV chimeric virus by passive infusion of neutralizing antibodies," Nature Medicine, vol. 6, no. 2, pp. 207-210, 2000.

[41] J. R. Mascola, M. G. Lewis, G. Stiegler et al., "Protection of macaques against pathogenic simian/human immunodeficiency virus $89.6 \mathrm{PD}$ by passive transfer of neutralizing antibodies," Journal of Virology, vol. 73, no. 5, pp. 4009-4018, 1999.

[42] R. S. Veazey, R. J. Shattock, M. Pope et al., "Prevention of virus transmission to macaque monkeys by a vaginally applied 
monoclonal antibody to HIV-1 gp120," Nature Medicine, vol. 9, no. 3, pp. 343-346, 2003.

[43] N. L. Haigwood, D. C. Montefiori, W. F. Sutton et al., "Passive immunotherapy in simian immunodeficiency virus-infected macaques accelerates the development of neutralizing antibodies," Journal of Virology, vol. 78, no. 11, pp. 5983-5995, 2004.

[44] P. W. H. I. Parren, P. A. Marx, A. J. Hessell et al., "Antibody protects macaques against vaginal challenge with a pathogenic R5 simian/human immunodeficiency virus at serum levels giving complete neutralization in vitro," Journal of Virology, vol. 75, no. 17, pp. 8340-8347, 2001.

[45] P. Poignard, R. Sabbe, G. R. Picchio et al., "Neutralizing antibodies have limited effects on the control of established HIV-1 infection in vivo," Immunity, vol. 10, no. 4, pp. 431-438, 1999.

[46] M. C. Gauduin, P. W. H. I. Parren, R. Weir, C. F. Barbas, D. R. Burton, and R. A. Koup, "Passive immunization with a human monoclonal antibody protects hu-PBL- SCID mice against challenge by primary isolates of HIV-1," Nature Medicine, vol. 3, no. 12, pp. 1389-1393, 1997.

[47] C. Moog, H. J. A. Fleury, I. Pellegrin, A. Kirn, and A. M. Aubertin, "Autologous and heterologous neutralizing antibody responses following initial seroconversion in human immunodeficiency virus type 1-infected individuals," Journal of Virology, vol. 71, no. 5, pp. 3734-3741, 1997.

[48] A. Pinter, W. J. Honnen, S. C. Kayman, O. Trochev, and Z. Wu, "Potent neutralization of primary HIV-1 isolates by antibodies directed against epitopes present in the V1/V2 domain of HIV1 gp120," Vaccine, vol. 16, no. 19, pp. 1803-1811, 1998.

[49] Y. Cao, L. Qin, L. Zhang, J. Safrit, and D. D. Ho, "Virologic and immunologic characterization of long-term survivors of human immunodeficiency virus type 1 infection," New England Journal of Medicine, vol. 332, no. 4, pp. 201-208, 1995.

[50] P. Carotenuto, D. Looij, L. Keldermans, F. De Wolf, and J. Goudsmit, "Neutralizing antibodies are positively associated with $\mathrm{CD}^{+}{ }^{+} \mathrm{T}$-cell counts and T-cell function in long-term AIDS-free infection," AIDS, vol. 12, no. 13, pp. 1591-1600, 1998.

[51] D. C. Montefiori, G. Pantaleo, L. M. Fink et al., "Neutralizing and infection-enhancing antibody responses to human immunodeficiency virus type 1 in long-term nonprogressors," Journal of Infectious Diseases, vol. 173, no. 1, pp. 60-67, 1996.

[52] A. K. Pilgrim, G. Pantaleo, O. J. Cohen et al., "Neutralizing antibody responses to human immunodeficiency virus type 1 in primary infection and long-term-nonprogressive infection," Journal of Infectious Diseases, vol. 176, no. 4, pp. 924932, 1997.

[53] Y. J. Zhang, C. Fracasso, J. R. Fiore et al., "Augmented serum neutralizing activity against primary human immunodeficiency virus type 1 (HIV-1) isolates in two groups of HIV1- infected long-term nonprogressors," Journal of Infectious Diseases, vol. 176, no. 5, pp. 1180-1187, 1997.

[54] X. Wei, J. M. Decker, S. Wang et al., "Antibody neutralization and escape by HIV-1," Nature, vol. 422, no. 6929, pp. 307-312, 2003.

[55] A. Trkola, H. Kuster, P. Rusert et al., "Delay of HIV-1 rebound after cessation of antiretroviral therapy through passive transfer of human neutralizing antibodies," Nature Medicine, vol. 11, no. 6, pp. 615-622, 2005.

[56] N. L. Haigwood, A. Watson, W. F. Sutton et al., "Passive immune globulin therapy in the SIV/macaque model: early interventisn can alter disease profile," Immunology Letters, vol. 51, no. 1-2, pp. 107-114, 1996.
[57] Y. Nishimura, T. Igarashi, N. L. Haigwood et al., "Transfer of neutralizing IgG to macaques $6 \mathrm{~h}$ but not $24 \mathrm{~h}$ after SHIV infection confers sterilizing protection: implications for HIV1 vaccine development," Proceedings of the National Academy of Sciences of the United States of America, vol. 100, no. 25, pp. 15131-15136, 2003.

[58] H. Yamamoto, M. Kawada, A. Takeda, H. Igarashi, and T. Matano, "Post-infection immunodeficiency virus control by neutralizing antibodies," PloS One, vol. 2, no. 6, p. e540, 2007.

[59] A. J. Hessell, P. Poignard, M. Hunter et al., "Effective, low-titer antibody protection against low-dose repeated mucosal SHIV challenge in macaques," Nature Medicine, vol. 15, no. 8, pp. 951-954, 2009.

[60] A. J. Hessell, E. G. Rakasz, D. M. Tehrani et al., "Broadly neutralizing monoclonal antibodies 2F5 and 4E10 directed against the human immunodeficiency virus type 1 gp41 membraneproximal external region protect against mucosal challenge by simian-human immunodeficiency virus SHIVBa-L," Journal of Virology, vol. 84, no. 3, pp. 1302-1313, 2010.

[61] N. Goonetilleke, M. K. P. Liu, J. F. Salazar-Gonzalez et al., “The first $\mathrm{T}$ cell response to transmitted/founder virus contributes to the control of acute viremia in HIV-1 infection," Journal of Experimental Medicine, vol. 206, no. 6, pp. 1253-1272, 2009.

[62] S. Jain, A. J. Patrick, and K. L. Rosenthal, "Multiple tandem copies of conserved gp41 epitopes incorporated in gag viruslike particles elicit systemic and mucosal antibodies in an optimized heterologous vector delivery regimen," Vaccine, vol. 28, no. 43, pp. 7070-7080, 2010.

[63] O. Alsmadi, R. Herz, E. Murphy, A. Pinter, and S. A. Tilley, "A novel antibody-dependent cellular cytotoxicity epitope in gp120 is identified by two monoclonal antibodies isolated from a long-term survivor of human immunodeficiency virus type 1 infection," Journal of Virology, vol. 71, no. 2, pp. 925933, 1997.

[64] R. A. Koup, J. E. Robinson, Q. V. Nguyen et al., "Antibody-dependent cell-mediated cytotoxicity directed by a human monoclonal antibody reactive with gp120 of HIV-1," AIDS, vol. 5, no. 11, pp. 1309-1314, 1991.

[65] O. Alsmadi and S. A. Tilley, "Antibody-dependent cellular cytotoxicity directed against cells expressing human immunodeficiency virus type 1 envelope of primary or laboratoryadapted strains by human and chimpanzee monoclonal antibodies of different epitope specificities," Journal of Virology, vol. 72, no. 1, pp. 286-293, 1998.

[66] K. Broliden, A. Von Gegerfelt, C. Persson et al., "Identification of cross-reactive antigenic target regions for HIV type 1-specific antibody-dependent cellular cytotoxicity," AIDS Research and Human Retroviruses, vol. 12, no. 18, pp. 1699-1702, 1996.

[67] D. S. Tyler, S. D. Stanley, S. Zolla-Pazner et al., "Identification of sites within gp41 that serve as targets for antibody-dependent cellular cytotoxicity by using human monoclonal antibodies," Journal of Immunology, vol. 145, no. 10, pp. 32763282, 1990.

[68] U. H. M. Ziegner, I. Frank, A. Bernatowicz, S. E. Starr, and H. J. Streckert, "Antibody-dependent cellular cytotoxicity (ADCC) is directed against immunodominant epitopes of the envelope proteins of human immunodeficiency virus 1 (HIV-1)," Viral Immunology, vol. 5, no. 4, pp. 273-281, 1992.

[69] M. Duval, M. R. Posner, and L. A. Cavacini, "A bispecific antibody composed of a nonneutralizing antibody to the gp41 immunodominant region and an anti-CD89 antibody directs broad human immunodeficiency virus destruction by neutrophils," Journal of Virology, vol. 82, no. 9, pp. 4671-4674, 2008. 
[70] R. H. Florese, T. Demberg, P. Xiao et al., "Contribution of nonneutralizing vaccine-elicited antibody activities to improved protective efficacy in rhesus macaques immunized with Tat/ Env compared with multigenic vaccines," Journal of Immunology, vol. 182, no. 6, pp. 3718-3727, 2009.

[71] T. Yamada and A. Iwamoto, "Expression of a novel Nef epitope on the surface of HIV type 1-infected cells," AIDS Research and Human Retroviruses, vol. 15, no. 11, pp. 1001-1009, 1999.

[72] T. Yamada, N. Watanabe, T. Nakamura, and A. Iwamoto, "Antibody-dependent cellular cytotoxicity via humoral immune epitope of nef protein expressed on cell surface," Journal of Immunology, vol. 172, no. 4, pp. 2401-2406, 2004.

[73] A. J. Hessell, L. Hangartner, M. Hunter et al., "Fc receptor but not complement binding is important in antibody protection against HIV," Nature, vol. 449, no. 7158, pp. 101-104, 2007.

[74] V. R. Gómez-Román, L. J. Patterson, D. Venzon et al., "Vaccine-elicited antibodies mediate antibody-dependent cellular cytotoxicity correlated with significantly reduced acute viremia in rhesus macaques challenged with SIV $_{\text {mac251 }}$," Journal of Immunology, vol. 174, no. 4, pp. 2185-2189, 2005.

[75] G. Isitman, A. W. Chung, M. Navis, S. J. Kent, and I. Stratov, "Pol as a target for antibody dependent cellular cytotoxicity responses in HIV-1 infection," Virology, vol. 412, no. 1, pp. 110-116, 2011.

[76] I. Stratov, A. Chung, and S. J. Kent, "Robust NK cell-mediated human immunodeficiency virus (HIV)-specific antibodydependent responses in HIV-infected subjects," Journal of Virology, vol. 82, no. 11, pp. 5450-5459, 2008.

[77] G. Isitman, A. Chung, M. Navis, I. Stratov, and S. Kent, "ADCC immunity to HIV-1 Pol," in Proceedings of the Annual Conference of the Australasian Society for HIV Medicine (ASHM '11), Canberra, Australia, 2011.

[78] S. Rerks-Ngarm, P. Pitisuttithum, S. Nitayaphan et al., "Vaccination with ALVAC and AIDSVAX to prevent HIV-1 infection in Thailand," New England Journal of Medicine, vol. 361, no. 23, pp. 2209-2220, 2009.

[79] B. Haynes, AIDS Vaccine, Bangkok, Thailand, 2011.

[80] V. Peut and S. J. Kent, "Substantial envelope-specific CD8 Tcell immunity fails to control siv disease," Virology, vol. 384, no. 1, pp. 21-27, 2009.

[81] A. D. Kelleher, C. Long, E. C. Holmes et al., "Clustered mutations in HIV-1 gag are consistently required for escape from HLA-B27-restricted cytotoxic T lymphocyte responses," Journal of Experimental Medicine, vol. 193, no. 3, pp. 375-385, 2001.

[82] L. L. Lanier, "Up on the tightrope: natural killer cell activation and inhibition," Nature Immunology, vol. 9, no. 5, pp. 495-502, 2008.

[83] G. Alter, M. P. Martin, N. Teigen et al., "Differential natural killer cell-mediated inhibition of HIV-1 replication based on distinct KIR/HLA subtypes," Journal of Experimental Medicine, vol. 204, no. 12, pp. 3027-3036, 2007.

[84] M. P. Martin, X. Gao, J. H. Lee et al., "Epistatic interaction between KIR3DS1 and HLA-B delays the progression to AIDS," Nature Genetics, vol. 31, no. 4, pp. 429-434, 2002.

[85] G. Alter, D. Heckerman, A. Schneidewind et al., "HIV-1 adaptation to NK-cell-mediated immune pressure," Nature, vol. 476, no. 7358, pp. 96-101, 2011. 

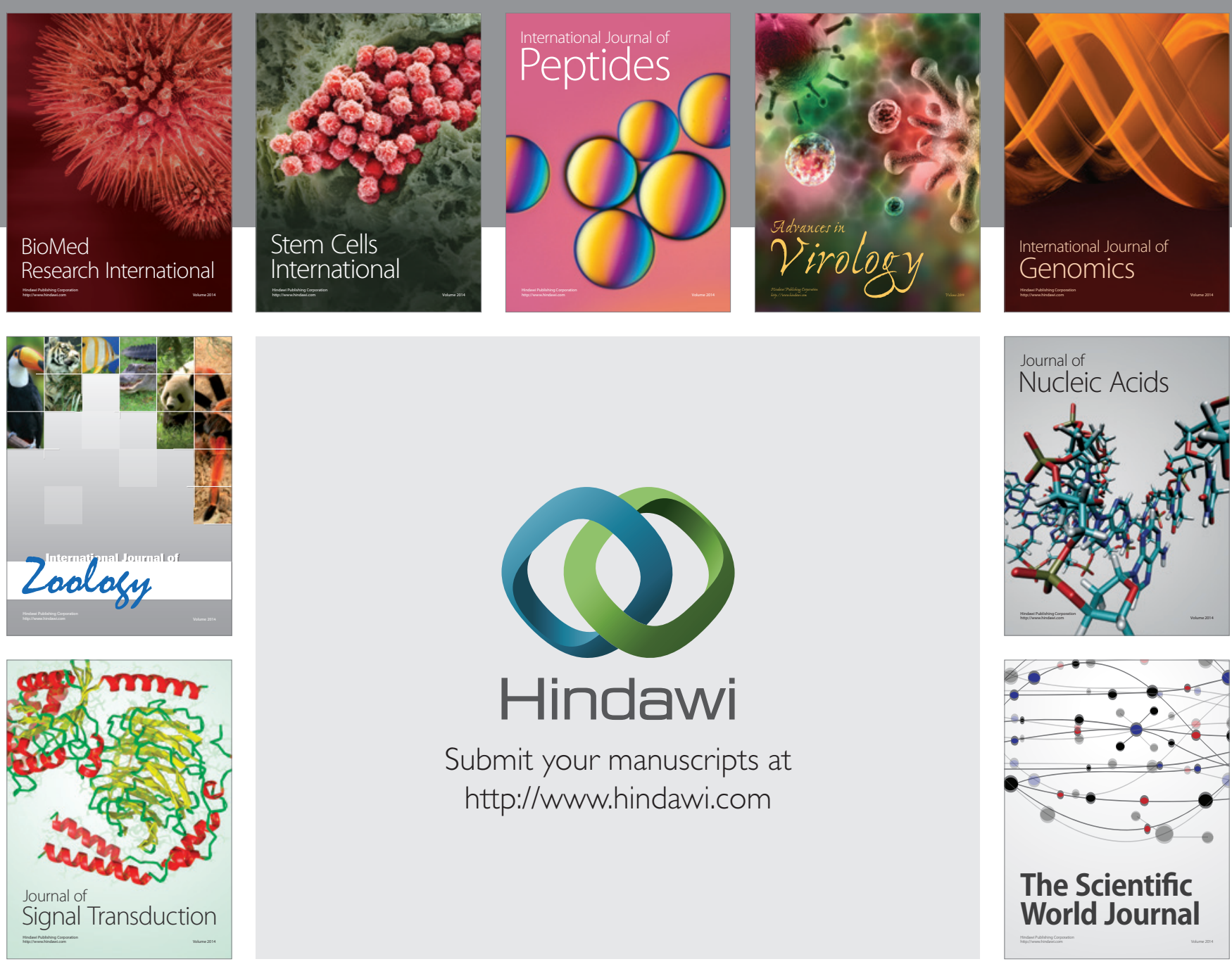

Submit your manuscripts at

http://www.hindawi.com
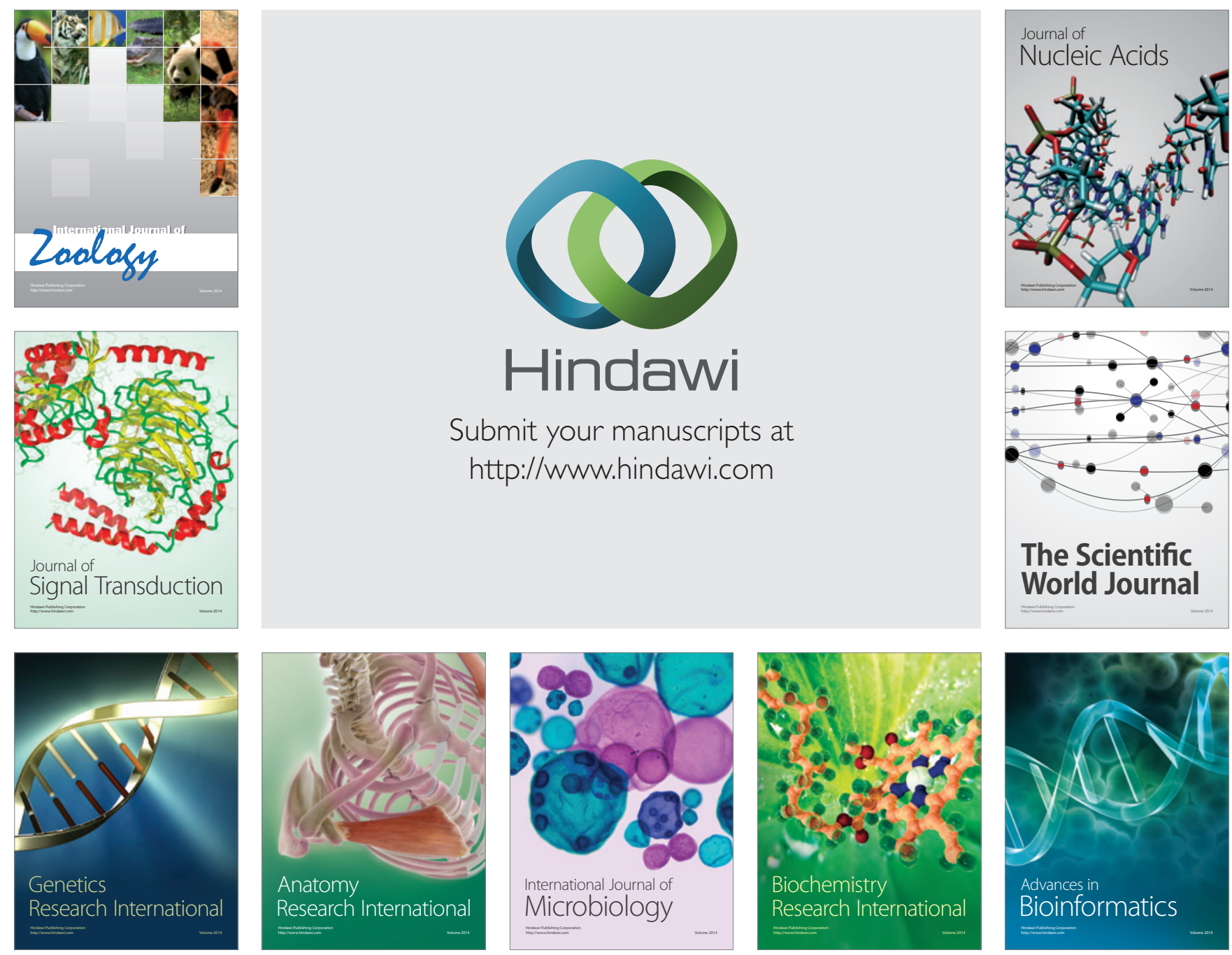

The Scientific World Journal
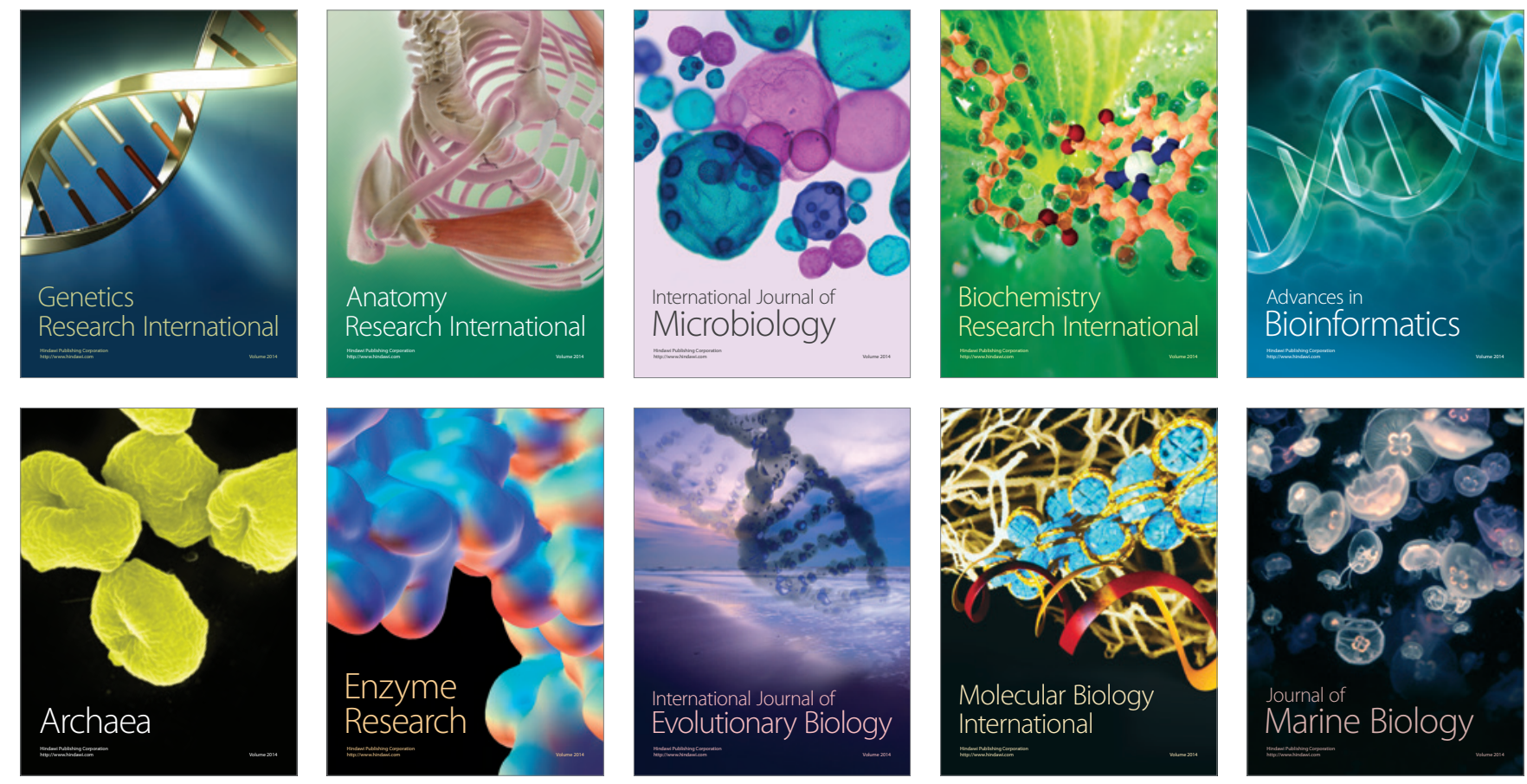